Research Article

\title{
Evaluation of anti- inflammatory activity of aqueous extract of Mangifera indica leaves in albino rats
}

\author{
A. Sudha Madhuri*, Rajalakshmi Mohanvelu, S. Ramabhimaiah
}

\begin{abstract}
Department of Pharmacology, Navodaya Medical College, Raichur, Karnataka, India

Received: 03 May 2016

Revised: 09 May 2016

Accepted: 12 May 2016

*Correspondence to:

Dr. A. Sudha Madhuri, Email: allellisudhamadhuri @ gmail.com
\end{abstract}

Copyright: (C) the author(s), publisher and licensee Medip Academy. This is an openaccess article distributed under the terms of the Creative Commons Attribution NonCommercial License, which permits unrestricted noncommercial use, distribution, and reproduction in any medium, provided the original work is properly cited.

\begin{abstract}
Background: Mangifera indica (MI) commonly known as mango belongs to the family anacardiaceae, distributed in rural and semi urban parts of India. According to Ayurveda, various medical properties are attributed to different parts of the mango tree. The purpose of the study was to evaluate antiinflammatory activity of aqueous extract of Mangifera indica leaves.

Methods: Aqueous extract of Mangifera indica leaves was prepared and tested for anti-inflammatory activity in albino rats weighing 200-250 gm. The in vivo anti-inflammatory activity was evaluated by using Acute (carrageenan induced paw edema) and chronic (Formalin induced paw edema) animal models. Rats were divided into 4 groups, 6 rats in each group. Group I (control) received 0.1 $\mathrm{ml} 4 \%$ gum acacia suspension. Group II and Group III received Mangifera indica extract at doses of $200 \mathrm{mg} / \mathrm{kg}$ and $400 \mathrm{mg} / \mathrm{kg}$ body weight. Group IV (standard) received diclofenac $10 \mathrm{mg} / \mathrm{kg}$ body weight. All the drugs were administered orally. Anti-inflammatory activity was expressed as percentage inhibition of paw edema.

Results: The percentage inhibition in carrageenan induced paw edema with 200 $\mathrm{mg} / \mathrm{kg}$ and $400 \mathrm{mg} / \mathrm{kg}$ Mangifera indica extract was $44.8 \%$ and $53 \%$ and in formalin induced paw edema was $47.5 \%$ and $64.4 \%$ respectively. The two doses of Mangifera indica extract showed significant anti-inflammatory action $(\mathrm{p}<0.001)$ in both models.
\end{abstract}

Conclusions: Aqueous extract of Mangifera indica leaves showed significant dose dependent anti-inflammatory activity.

Key words: Anti-inflammatory activity, Carrageenan, Edema, Formalin, Mangifera indica

\section{INTRODUCTION}

Inflammation is considered as a primary physiologic defense mechanism that helps body to protect itself against infections, burns, toxic chemicals, allergens or other noxious stimuli. An uncontrolled and persistent inflammation may act as etiological factor for many chronic illnesses. ${ }^{1}$ Non-steroidal anti-inflammatory drugs (NSAIDS) are widely used in the treatment of pain and inflammation. Currently available NSAIDS are associated with unwanted side effects and have their own limitations. About $34-46 \%$ of the users of NSAIDS usually sustain some gastrointestinal damage due to inhibition of the protective cyclooxygenase enzyme in gastric mucosa. ${ }^{2}$ Hence there is a need for antiinflammatory drugs with fewer side effects.
Mangifera indica (anacardiaceae) is a large evergreen tree that grows to a height of 10-45 m, dome shaped with dense foliage, typically heavy branches from a stout trunk. $^{3}$

There are many traditional uses for different parts of Mangifera indica throughout the globe. Mangifera indica is used to treat asthma, cough, dysentery, diarrhea, pain, leucorrhoea and malaria. ${ }^{4}$ Pharmacological studies have demonstrated that Mangifera indica exhibits a wide range of properties like analgesic, anti-inflammatory, antidiabetic, antiulcer, antioxidant and immunomodulatory. ${ }^{6-9}$ The studies evaluating the antiinflammatory activity of Mangifera indica leaves are 
limited. The main purpose of the study was to evaluate anti-inflammatory activity of Mangifera indica leaves.

\section{METHODS}

Mangifera indica leaves available locally were identified and used for the study.

\section{Preparation of extracts}

The fresh leaves of Mangifera indica were shade dried for 2 weeks and grinded into a fine powder and passed through a sieve to made fine free flowing powder. The powder was soaked in equal amount of water and stirred intermittently and was left overnight. The macerated pulp was dried at reduced temperature. This dry mass served as aqueous extract of leaves of Mangifera indica for experimentation.

\section{Drugs and chemicals}

Diclofenac (win medicare), carrageenan (sigma), formalin and all other chemicals were analytical grade.

\section{Animals}

Adult albino rats of either sex, weighing between 200$250 \mathrm{gm}$ were used in this study. Animals were obtained from National Institute of Nutrition, Hyderabad, India. The animals were stabilized for one week at temperature $25 \pm 1^{\circ} \mathrm{C}$ and $60 \pm 5 \%$ relative humidity and $12 \mathrm{hrs}$ dark light cycles. They have been given a standard pellet diet and water ad libitum. All the experiments were conducted as per norms approved by institutional animal ethics committee.

\section{Experimental procedure}

The rats were randomly allocated into 4 groups $(n=6)$ and treated as follows.

Group I: Control received vehicle only $(0.1 \mathrm{ml} 4 \%$ gum acacia suspension)

Group II: Test rats received aqueous extract of leaves of Mangifera indica $200 \mathrm{mg} / \mathrm{kg}$.

Group III: Test rats received aqueous extract of leaves of Mangifera indica $400 \mathrm{mg} / \mathrm{kg}$.

Group IV: Standard received diclofenac $10 \mathrm{mg} / \mathrm{kg}$.
All the drugs were administered orally.

\section{Carrageenan induced rat paw edema model}

In this method, the rats were pre-treated with drugs, orally $1 \mathrm{hr}$ before the experiment. $0.1 \mathrm{ml}$ of $1 \%$ carrageenan solution was injected into sub plantar region of the right hind paw of each rat.

The rat paw volume up to the ankle joint was measured at $0,1,2,3$ and 4 hours after the injection of carrageenan using plethysmometer. Increase in the paw edema volume was considered as the difference between initial at $0 \mathrm{hr}$ and of $1 \mathrm{hr}, 2 \mathrm{hr}$, $3 \mathrm{hr}$ or $4 \mathrm{hr}$. Percentage inhibition of paw volume treated and control groups were calculated as follows. ${ }^{10}$

$$
\text { Percent inhibition }=\frac{V c-V t}{V c} \times 100
$$

Where $\mathrm{Vc}$ and $\mathrm{Vt}$ represent the mean increase in paw volume in control and treated groups respectively.

\section{Formalin induced rat paw edema model}

$0.1 \mathrm{ml}$ of $2 \%$ formalin was injected in the sub plantar area of right hind paw of rat. All the drugs were administered orally $1 \mathrm{hr}$ prior to formalin injection and subsequently for 9 consecutive days. The second injection of formalin was given on third day. ${ }^{11}$ The paw volume was measured by plethysmometer on day 1 and day 9 . The difference in the paw volume on day 1 and day 9 was considered as inflammatory edema. Volume changes in standard and test groups were compared with that of control and percentage inhibition was calculated.

\section{Statistics}

Results were expressed as mean \pm SD. Statistical analysis was performed by using one way analysis of variance (ANOVA) followed by Dunnet's test. $\mathrm{P}<0.05$ was considered statistically significant.

\section{RESULTS}

Anti-inflammatory effect of Mangifera indica extract against carrageenan induced paw edema is shown in Table 1.

Table 1: Anti-inflammatory effect of aqueous extract of Mangifera indica in carrageenan induced paw edema.

\begin{tabular}{|c|c|c|c|c|}
\hline \multirow{2}{*}{$\begin{array}{l}\text { Treatment } \\
\text { group }\end{array}$} & \multicolumn{4}{|c|}{ Increase in paw volume in $\mathrm{ml}$ ( $\%$ inhibition of paw edema) } \\
\hline & 1 hour & 2 hour & 3 hour & 4 hour \\
\hline Control & $0.2811 \pm 0.0129$ & $0.3542 \pm 0.0130$ & $0.4343 \pm 0.0128$ & $0.3812 \pm 0.0254$ \\
\hline MI $200 \mathrm{mg} / \mathrm{kg}$ & $0.1782 \pm 0.0145 *(36.88)$ & $0.2018 \pm 0.0 .120 *(43.22)$ & $0.2310 \pm 0.0112 *(46.77)$ & $0.2102 \pm 0.0122 *(44.88)$ \\
\hline MI $400 \mathrm{mg} / \mathrm{kg}$ & $0.1932 \pm 0.0104 *(31.56)$ & $0.2098 \pm 0.0109 *(40.96)$ & $0.2172 \pm 0.0157 *(50)$ & $0.1798 \pm 0.0170 *(53.01)$ \\
\hline $\begin{array}{l}\text { Diclofenac } \\
(10 \mathrm{mg} / \mathrm{kg})\end{array}$ & $0.1372 \pm 0.01048 *(51.41)$ & $0.1747 \pm 0.0140 *(50.84)$ & $0.1555 \pm 0.009 *(64.28)$ & $0.1100 \pm 0.01361 *(71.12)$ \\
\hline
\end{tabular}

Results expressed as mean \pm SD. p $<0.001 *$ compared to control. Figures in parenthesis indicate percentage inhibition. 
The two doses of Mangifera indica extract $(200 \mathrm{mg} / \mathrm{kg}$ and $400 \mathrm{mg} / \mathrm{kg}$ ) showed statistically significant $(\mathrm{p}<0.001)$ inhibitory effect on "mean increase in paw volume" at all-time intervals (1, 2, 3 and 4 hours). Maximum percentage inhibition was observed at the end of four hours. The extract test doses $200 \mathrm{mg} / \mathrm{kg}$ and $400 \mathrm{mg} / \mathrm{kg}$ body weight reduced the edema induced by carrageenan by $44.8 \%$ and $53 \%$ respectively. The standard drug showed $71.1 \%$ of inhibition compared to control.

\section{Table 2: Anti-inflammatory effect of aqueous extract of Mangifera indica in formalin induced edema.}

\begin{tabular}{|lll|}
\hline $\begin{array}{l}\text { Treatment } \\
\text { group }\end{array}$ & $\begin{array}{l}\text { Increase in paw } \\
\text { volume in } \mathrm{ml}\end{array}$ & $\begin{array}{l}\text { Percentage } \\
\text { inhibition of } \\
\text { paw edema }\end{array}$ \\
\hline Control & $0.515 \pm 0.0920$ & - \\
\hline MI $200 \mathrm{mg} / \mathrm{kg}$ & $0.270 \pm 0.7127^{*}$ & $47.57 \%$ \\
\hline MI $400 \mathrm{mg} / \mathrm{kg}$ & $0.183 \pm 0.0454^{*}$ & $64.46 \%$ \\
\hline $\begin{array}{l}\text { Diclofenac } \\
(10 \mathrm{mg} / \mathrm{kg})\end{array}$ & $0.126 \pm 0.0350^{*}$ & $75.53 \%$ \\
\hline
\end{tabular}

Results expressed as mean \pm SD. $p<0.001$ compared to control.

Table 2 shows the anti-inflammatory effect of Mangifera indica extract in formalin induced paw edema. The percentage inhibition of edema at the end of nine days was $47.5 \%$ and $64.4 \%$ at the doses of $200 \mathrm{mg} / \mathrm{kg}$ and 400 $\mathrm{mg} / \mathrm{kg}$ respectively. The standard drug showed $75.5 \%$ of inhibition when compared to control. Mangifera indica extract $(200 \mathrm{mg} / \mathrm{kg}$ and $400 \mathrm{mg} / \mathrm{kg}$ ) showed statistically significant $(\mathrm{p}<0.001)$ inhibitory effect in formalin induced edema.

\section{DISCUSSION}

Carrageenan induced hind paw edema is the standard experimental model of acute inflammation. Carrageenan is phlogistic agent of choice for testing anti-inflammatory drugs as it is devoid of apparent systemic effects and more over the experimental model exhibits a high degree of reproducibility. ${ }^{12}$ Carrageenan induced paw edema is characterized by biphasic event with involvement of different inflammatory mediators. ${ }^{13}$ Histamine and serotonin plays important role in the first phase (during the first 2 hours after carrageenan injection) while in the second phase (3-4hours after carrageenan injection) kinins and prostaglandins are involved. ${ }^{14}$ Our results revealed that administration of Mangifera indica extract inhibit edema starting from the first hour and all phases of inflammation, which is probably due to inhibition of release of different chemical mediators of inflammation.

Formalin induced paw edema is the most suitable experimental model to screen antiarthritic and antiinflammatory agents as it closely resembles human arthritis. ${ }^{15}$ The nociceptive effect of formalin is biphasic, an early neurogenic component followed by a later tissue mediated response. Formalin induced paw edema in rats represents the proliferative phase of inflammation. ${ }^{16}$ Mangifera indica extract showed significant activity in this model. Therefore, it appears to act by inhibiting proliferative phase of inflammation.

The phyto chemical screening of Mangifera indica extract revealed the presence of polyphenolics, flavonoids, triterpenoids and tannins. ${ }^{17,18}$ These phyto constituents could be responsible for anti-inflammatory action.

Studies have demonstrated that crude leaf extract of Mangifera indica showed antibacterial activity. ${ }^{19}$ Therefore the additional property of antimicrobial along with anti-inflammatory activity of Mangifera indica leaves may have synergistic effects on the inflammation.

\section{CONCLUSION}

Aqueous extract of Mangifera indica leaves showed significant anti-inflammatory action in acute and chronic experimental models and the activity was dose dependent.

\section{Funding: No funding sources Conflict of interest: None declared \\ Ethical approval: The study was approved by the Institutional Ethics Committee}

\section{REFERENCES}

1. Kumar V, Abbas AK, Fausto N. In: Robbins and Cotran Pathological basis of disease. $7^{\text {th }} \mathrm{Ed}$, Philadelphia, Elsevier Saunders. 2004:47-86.

2. Rang HP, Dale MM, Ritter JM. Anti-inflammatory and immunosuppressant drugs, chapter 14. Flower RJ; Rang and Dale's Pharmacology, 6th Ed. Elsevier Publication. 2008;226-45.

3. Scartezzini P, Speroni E. Review on some plants of Indian traditional medicine with antioxidant activity. J Ethnopharmacol. 2000;71:2343.

4. Gilles LS. Ethnomedical uses of plants in Nigeria. Benin: University of Benin press. 1992;46.

5. Islam MR, Mannan MA, Kabir MHB, Islam A, Olival KJ. Analgesic, anti-inflammatory and antimicrobial effects of ethanol extract of mango leaves. J Bangladesh Agril Univ. 2010;8(2):239-44.

6. Luka CD, Mohammed A. Evaluation of the antidiabetic property of aqueous extract of Mangifera indica leaf on normal and alloxan- induced diabetic rats. J Nat Prod Plant Resour. 2012;2(2):239-43.

7. Carvalho AC, Guedes MM, Desouza AL, Trevisan MT, Lima AF, Santos FA et al. Gastroprotective effect of mangiferin: A xanthonoid from Mangifera indica against gastric injury induced by ethanol and indomethacin in rodents. Planta Med. 2007;73:13726.

8. Martínez G, Delgado R, Pérez G, Garrido G, Núñez Sellés AJ, León OS. Evaluation of the in-vitro antioxidant activity of Mangifera indica: Extract (vimang) phytother Res. 2004;14:424-7. 
9. Manna SK, Kuo MT, Aggarwal BB. Over expression of gamma-glutamyl cysteine synthatase suppresses tumor necrosis factor-induced apoptosis and activation of nuclear transcription factor-KappaB and activator protein-1. Oncogene. 1999;18(30):4371-82.

10. Winter CA, Risely EA, Nusa CW. Carrageenaninduced oedema in the hind paw of the rat as an assay for anti-inflammatory drugs, Proc. Soc Exp Biol Med. 1962;111:544-7.

11. Hosseinzadeh H, Younesi H. Antinoceptive and antiinflammatory effects of crocus sativas L stigma and petal extracts in mice, BMC Pharmacol. 2002;2:1.

12. Patel A, Patel T, Macwan C, Patel M, Chauhan K, Patel J. Evaluation of Anti-inflammatory and Analgesic activity of roots of Rubia cordifolia in rats. J Pharm Sci Res. 2010;2(12):809-13.

13. Hernandez PM, Gallego RR. Evaluation of the antiinflammatory and analgesic activity of sideritis anariensis Var. Pannosa in mice. J Ethanopharmacol. 2002;81:43-7.

14. Chawla AS, Singh M, Murthy MS, Guptha MP, Singh H. Anti-inflammatory action of ferulic acid and its ester in carrageenan induced rat paw edema model. Indian J Exp Biol.1987;25:187-9.
15. Greenwald RA. Animal model for evaluation of arthritic drugs. Methods and findings in Experimental and clinical pharmacology. 1991;13:75-83.

16. Ahamed Z, Ramabhimaiah S. Anti-inflammatory activity of Aqueous Extract of Carica papaya seeds in Albino Rats. Biomed Pharmacol J. 2012;5;173-7.

17. Núñez Sellés AJ, Vélez Castro HT, Agüero-Agüero J, González-González J, Naddeo F, De Simone F, et al. Isolation and quantitative analysis of phenolic antioxidants free sugar and polyols mango (Mangifera indica Linn) stem bark aqueous decoction used in Cuba as a nutritional supplement. J Agri Food Chem. 2002;50:762-6.

18. Khan MA, Nizami SS, Khan MNI, Azeem SW, Ahmed Z. New triterpenes from Mangifera indica. J Nat Prod. 1994;28:124-30.

19. Doughari JH, Manzara S. Invitro antibacterial activity of crude leaf extract of Mangifera indica linn. African J Microbiol Res. 2008(2):67-72.

Cite this article as: Madhuri AS, Mohanvelu R, Ramabhimaiah S. Evaluation of anti- inflammatory activity of aqueous extract of Mangifera indica leaves in albino rats. Int J Basic Clin Pharmacol 2016;5:635-8. 